\title{
The importance of prenol lipids in mitigating salt stress in the leaves of Tilia $\times$ euchlora trees
}

\author{
Aneta H. Baczewska-Dąbrowska ${ }^{1}$ - Wojciech Dmuchowski ${ }^{2}$ Dariusz Gozdowski ${ }^{3} \cdot$ Barbara Gworek $^{2}$. \\ Adam Jozwiak $^{4,5} \cdot$ Ewa Swiezewska $^{4} \cdot$ Piotr Dąbrowski $^{3} \cdot$ Irena Suwara $^{3}$
}

Received: 16 July 2021 / Accepted: 3 September 2021 / Published online: 21 September 2021

(c) The Author(s) 2021

\begin{abstract}
Key message Plants use multiple mechanisms to deal with salt stress. Salt stress increases the content of polyprenols in Tilia's leaves, which may mitigate stress.

Abstract De-icing salt has been used on streets and pavements in most northern countries since the 1960s. Salt stress limits all vital functions of trees. Tilia $\times$ euchlora is planted in many cities given its unique decorative qualities. The aim of this study was to determine the tree strategy to mitigate salt stress due to the synthesis of polyprenols in leaves. Many years of observations have demonstrated that trees of the same species growing in the same street conditions may have extremely different health statuses. The study consisted of two experiments: a field experiment with urban street trees growing in saline soils and a controlled pot experiment with young trees exposed to increasing doses of salt. The differences between the young trees from the pot experiment and older trees from the field experiment were expressed in their ability to synthesize polyprenols. In urban conditions, the tree leaves with less damage contained significantly more polyprenols than did those with more damage. The salt stress mitigation strategy may be related to the ability to synthesize polyprenols. This ability can be acquired through adaptation by older trees. The mechanism involves limiting the transport of $\mathrm{Cl}^{-}$and $\mathrm{Na}^{+}$to leaves. In the pot experiment, the young trees did not exhibit this ability.
\end{abstract}

Keywords Urban trees $\cdot$ Salt stress $\cdot$ Polyprenols $\cdot$ Ionic balance $\cdot$ Tilia, deicing

\section{Introduction}

Communicated by R. Guy.

This article belongs to the Topical Collection: Salinity.

Aneta H. Baczewska-Dąbrowska

a.baczewska-dabrowska@obpan.pl

1 Polish Academy of Sciences Botanical Garden, Center for Conservation of Biological Diversity, Warsaw, Poland

2 Institute of Environmental Protection, National Research Institute, Warsaw, Poland

3 Warsaw University of Life Sciences, SGGW, Warsaw, Poland

4 Institute of Biochemistry and Biophysics, Polish Academy of Sciences, Warsaw, Poland

5 Present Address: Department of Plant and Environmental Sciences, Weizmann Institute of Science, 7610001 Rehovot, Israel
Urban trees provide a variety of uncountable ecosystem services, such as health, economic, psychological, social, and esthetic services (Dadvand et al. 2016; Livesley et al. 2016). Only healthy trees in good condition can perform these functions to improve the living conditions of city dwellers (Martin et al. 2016; Hallett et al. 2018). Based on many years of research, McPherson (2004) calculated that statistically one tree growing in an urban area in 40 years of life confers benefits totaling $\$ 3.117$.

De-icing of streets and sidewalks has been common in countries of the Northern Hemisphere since 1960s (Pauleit et al. 2002). The amount of salt used during the winter is not determined by negative temperatures but by the frequency of the transition from temperatures above zero to negative values. Salt stress affects the health of trees at the molecular, cellular, and histological levels. These changes are caused by the combined osmotic stress, which is related to the high osmotic pressure in the salinized soils, and the 
toxicity stress due to the excessive tissue concentrations of $\mathrm{Na}^{+}$and $\mathrm{Cl}^{-}$ions. Salt stress disrupts most of the key metabolic processes in trees, including photosynthesis, enzyme synthesis, lipid metabolism, and energy processes (Equiza et al. 2017; Sarker and Oba 2018; Nikolaeva et al. 2019; Zhou et al. 2019; Łuczak et al. 2021).

In response to salinity, plants have developed a variety of defense mechanisms. Resistance can include avoidance, tolerance and a combination of these two methods of defense against the stress factor (Blomqvist 1998). The following methods can be used to relieve salt stress by trees: inhibition of $\mathrm{Cl}$ and $\mathrm{Na}$ uptake and redistribution of elements from leaves to other parts of plants (Shelkeet al. 2019), the storage of $\mathrm{Na}^{+}$and $\mathrm{Cl}^{-}$in cell structures (Baetz et al. 2016), the induction of antioxidant enzymes and hormones (Zhao et al. 2019; Sarker and Oba 2020), the presence of ectomycorrhizal fungi (Zwiazek et al. 2019; Olchowik et al. 2021), the accumulation of compatible compounds, the increased conversion of xanthophyll pigments (Baraldi et al. 2019), and the presence of genes that can increase salt tolerance (Parihar et al. 2015).

Polyprenols belong to the group of compounds known as plant secondary metabolites (PSMs). Polyprenols play important defense functions against environmental stresses and attacks by pathogens (Satish et al. 2020). Polyisoprene alcohols are macromolecular polymers with different carbon chain lengths ranging from 5 to more than 100 isoprene units connected together according to the "head-to-tail" mechanism. (Swiezewska et al. 1994). Although prenols are common in plants, their role has not been fully explained thus far.

The qualitative composition and share of individual homologues in the total pool of these compounds has a gausoidal system unique for a given species, and in the case of plants, is characteristic of the genus and botanical family (Swiezewska and Danikiewicz 2005). Polyprenols occur most often in the cell membrane, probably affecting its fluidity and stability (Gutkowska et al. 2004; Skorupińska-Tudek et al. 2008). Polyprenols influence plant photosynthetic performance by modulating the dynamics of the thylakoid membrane (Akhtar et al. 2017). Presumably, polyprenols act as free radical scavengers in membranes (Bergamini 2003; Bajda et al. 2009). According to Bajda et al. (2005), polyprenols can play a special role in the adaptation of plants to adverse environmental conditions. Zhang et al. (2008) showed that dolichols, which are long-chain saturated polyisoprenoids, affect the plant response to drought and darkness-induced aging in Arabidopsis.

The increase in the synthesis of polyprenols is postulated to be a defensive strategy developed in $T$. $\times$ euchlora trees to salt stress (Milewska-Hendel et al. 2017). It cannot be excluded that polyprenols are involved in the regulation of chloride and sodium deposition in leaves. Baczewska et al.
(2014) suggested that polyprenols have an effect on reducing the accumulation of $\mathrm{Cl}^{-}$in urban street trees in Tilia, and Dmuchowski et al. (2019) found similar results for Gingko biloba. Polyprenols play a special role in mangrove trees. Basyuni et al. $(2017,2019)$ suggested their significant role in withstanding salt stress and/or water stress.

The literature review showed a relationship between the content of prenols and sodium and chlorine in leaves and the health condition of trees. It was noted in the study that Tilias growing under comparable conditions significantly differed in the degree of damage to the leaves and the content of $\mathrm{Cl}$, $\mathrm{Na}$ and prenol in them. Observations conducted for many years have indicated the existence of Crimean linden trees with a healthy appearance and trees that have visible symptoms of damage in the same habitat. The aim of this study was, therefore, to answer the question of whether thy trees can develop a defensive strategy based on the ability to synthesize larger amounts of polyprenols in the leaves to alleviate salt stress. The research presented in this publication is an extension of the preliminary work published by Baczewska et al. (2014). As an additional model, young trees were tested with controlled increases in soil salinity.

\section{Materials and methods}

The study was performed on trees belonging to one species, T. $\times$ euchlora $\mathrm{K}$. Koch. This tree has been known since the mid-nineteenth century and is cultivated in many countries of Central and Western Europe, where it grows in the wild and is commonly used for urban vegetation in public parks and along streets (Weryszko-Chmielewska et al. 2019).

In the field experiment, research was localized in the center of Warsaw (Poland). The trees grew on the lawn between the streets of Żwirki and Wigury Avenue (134 trees). The control trees ( 8 trees) grew in a green area $150 \mathrm{~m}$ from the avenue. No more suitable trees were found in the control area, but the leaves of all control trees showed no damage at all throughout the growing season. Żwirki and Wigury Avenue connect the main airport with the city center, which results in heavy vehicle traffic. In winter, black ice on the street is removed using $\mathrm{NaCl}$. There is no reason why any parts of the street would receive a higher or lower dose of salt.

Street and park trees (control) were also of the same age and from the same nursery and were planted simultaneously. The only difference was the salinity of the soil. The distance between the street trees was $10 \mathrm{~m}$ and the trees were $4 \mathrm{~m}$ from the roadway. Basic methodological information about the conditions of the experiment with T. $\times$ euchlora street and control trees as well as a pot experiment with young trees treated with different amounts of $\mathrm{NaCl}$ are presented in Table 1. 
Table 1 Basic methodological information about the conditions of the experiment with. Tilia $\times$ euchlora street and control trees as well as a pot experiment with young trees treated with different amounts of $\mathrm{NaCl}$

\begin{tabular}{|c|c|c|c|c|}
\hline \multirow[b]{3}{*}{ Number of trees } & \multicolumn{2}{|c|}{ Field experiment } & \multicolumn{2}{|l|}{ Pot experiment } \\
\hline & Control & & Control & \\
\hline & 134 & 8 & $2 \times 8$ & 8 \\
\hline Age of trees & 80 & 80 & 5 & 5 \\
\hline Date of salt addition & Winter & Winter & March 2018 & March 2018 \\
\hline Date of samples collection & $\begin{array}{l}\text { Middle of } \\
\text { July } 2018\end{array}$ & $\begin{array}{l}\text { Middle of } \\
\text { July } 2018\end{array}$ & Middle of July 2018 & Middle of July 2018 \\
\hline $\begin{array}{l}\text { Number of leaves collected } \\
\text { from single tree }\end{array}$ & 120 & 120 & All $(\sim 80)$ & All $(\sim 80)$ \\
\hline Trunk diameter & $\sim 20 \mathrm{~cm}$ & $\sim 20 \mathrm{~cm}$ & $3-3.5 \mathrm{~cm}$ & $3-3.5 \mathrm{~cm}$ \\
\hline
\end{tabular}

In the field experiment, the leaves were cut from the twigs from a height of $2-4 \mathrm{~m}$. The sampling date was mid-July, which is when the first damage occurred. Mid-July is recommended for collecting leaves for chemical analysis because at a later date, significantly magnified damage will distort the results of chemical analyses.

The field tests were supplemented with experiments performed on the same species under controlled conditions in pots. The experiment was organized in a park on the outskirts of the city. Five-year-old T. $\times$ euchlora trees were placed in 10-L containers directly on the ground and filled with soil consisting of light loamy silt under the mud. The containers were covered with soil to protect the roots of the trees from overheating and over drying. The linden seedlings were treated once in mid-March with salt at 0 (control), 15 and $30 \mathrm{~g}$ of $\mathrm{NaCl}$ dissolved in $250 \mathrm{~mL}$ of water. The containers were placed outside and watered by rain. During the experiment, seedlings were watered twice, supplementing the natural watering. Fertilization was not applied. In midJuly, all the leaves were torn off, and the experiment ended.

\section{Health condition of the leaves}

The health condition of trees was assessed on the basis of the degree of leaf damage. This classification consists of six categories of leaf damage index: where " 0 " indicates that the leaves had no damage; "1" indicates that damage covered up to $10 \%$ of the leaf surface; " 2 " damage covered 10-25\%; "3"-25-50\%; "4"-50-75\%; and " 5 " indicates a seriously damaged (damage to more than $75 \%$ of the leaf surface). The damage index was based on the assessment of combined leaf necrosis and chlorosis. The assessment of chlorosis and necrosis separately turned out to be practically impossible due to the large number of trees. Damage observations were carried out in mid-July. Determination of the leaf damage index in both experiments was carried out in mid-July. In the field experiment, damage index of the leaves was also assessed in mid-September, and such an assessment was impossible in the pot experiment because the experiment was completed.

\section{Chemical analysis of the leaves}

After collection, washing the leaves was abandoned due to the possibility of rinsing, especially $\mathrm{P}$ but also to a lesser extent $\mathrm{Na}^{+}$and $\mathrm{Cl}^{-}$, which would have an impact on the result. The samples were dried in the laboratory at $70{ }^{\circ} \mathrm{C}$ and ground in a Fritsh 14702 grinder.

Then, mineralization of the dry leaves was performed in a muffle furnace. The ash was dissolved in $30 \% \mathrm{HCl}$. Metals and $\mathrm{P}$ were determined by atomic spectrophotometry using a Perkin Elmer 1100B apparatus. $\mathrm{Cl}^{-}$was determined by potentiometric titration with an ion-selective electrode and the Orion Star Plus apparatus. $\mathrm{N}$ was determined by the Kjeldahl method using a Foss Tecator, and the LECO 132 apparatus was used to determine the content of S.

To calculate the ion balance index, the content of elements in leaves was converted into equivalent values (meq/100 g dry mass of leaves) by dividing the obtained result in a mass unit by atomic weight and valence. By calculating the data in this manner, it is possible to calculate the equilibrium state in plants and thus to compare electrochemically equivalent data. The organic acid content was calculated according to the method proposed by Van Tuil et al. (1964) as the difference between the sum of cations and the sum of anions $\left(\mathrm{R}-\mathrm{COO}^{-}=\left(\sum_{\mathrm{K}}-\sum_{\mathrm{A}}\right)\right.$. The ratio of the sum of organic acids to the sum of mineral anions $-\sum_{\mathrm{A}}$ was calculated as an indicator of the ionic balance in the leaves. The $\mathrm{NO}_{3}{ }^{-}$content was not included in the calculations due to the presence of trace amounts in the leaves. Four ions were used to calculate the sum of cations $-\sum_{\mathrm{K}}$ (De Wit et al. 1963; Brogowski et al. 2000):

$\Sigma_{\mathrm{A}}=\mathrm{H}_{2} \mathrm{PO}_{4}^{-}+\mathrm{SO}_{4}{ }^{2-}+\mathrm{Cl}^{-} ; \sum_{\mathrm{K}}=\mathrm{Ca}^{2+}+\mathrm{Mg}^{2+}+$ $\mathrm{K}^{+}+\mathrm{Na}^{+}$.

The quality control (QC) of the results of the chemical determinations was performed with certified reference materials: apple leaves (1515) from the National Institute of Standards and Technology (USA). The recovery range was from 90 to $95 \%$. 


\section{Qualitative and quantitative analyses of polyprenols}

To the dried and milled ground leaves $(50 \mathrm{mg}), 1 \mathrm{~mL}$ of an acetone:methanol mixture $(1: 1, \mathrm{v} / \mathrm{v})$ and internal standard (prenol 15, $50 \mu \mathrm{L}, \mathrm{C}-1 \mu \mathrm{g} / \mu \mathrm{L}$ ) from the Collection of polyprenols, Institute of Biochemistry and Biophysics, PAS were added and then incubated at $37{ }^{\circ} \mathrm{C}$ for $30 \mathrm{~min}$. The sample was centrifuged, and the supernatant was decanted. The pellets were re-extracted in $1 \mathrm{~mL}$ of acetone-hexane mixture (1:1) in an ultrasound bath and centrifuged again. The combined supernatant residues were evaporated in a nitrogen stream. The hydrolysing mixture was added $(0.5$ $\mathrm{mL}$ ) and heated for $1 \mathrm{~h}$ at $95{ }^{\circ} \mathrm{C}$ (Jozwiak et al. 2013). After hydrolysis, the lipids were purified as described earlier by Skorupinska-Tudek et al. (2008).

The lipids were isolated by column chromatography on silica gel in hexane. The latter fraction was evaporated in a nitrogen stream, dissolved in $200 \mu \mathrm{L}$ of IPA-EtOH mixture and analyzed by HPLC/UV detector (Waters 2487) according to the methodology of Skorupinska-Tudek et al. (2008) using a combination of linear gradients of solvent mixtures A (90\% methanol in water, v/v) and B (50\% methanol, 25\% hexane and $25 \%$ isopropanol $\mathrm{v} / \mathrm{v} / \mathrm{v}$ ) at a flow of $1.5 \mathrm{~mL} / \mathrm{min}$.

The signal from the Waters photodiode detector (2487) was recorded in the form of a series of chromatograms in the wavelength range $210-254 \mathrm{~nm}$. Separated compounds were identified on the basis of comparison of their retention times and absorption spectra with appropriate parameters of an external standard polyprenol mixture. The results were integrated at 210-nm wavelength in the Empower Pro program. The content of identified prenols was calculated considering the internal standard and administered in $\mathrm{mg}$ per $1 \mathrm{~g}$ of plant tissue dry matter. In the leaves, the contents of four polyprenols, pren-9, pren-10, pren-11 and pren-12, were identified and determined. Only the sum of polyprenols was used during further studies.

\section{Soil analysis}

Soil samples were obtained from nine randomly selected trees from each category of leaf damage index and control area. Four samples were collected in four directions at $1.5 \mathrm{~m}$ from each randomly selected tree. The mixed sample for each tree was separately analyzed. Soil samples for testing were obtained from depths of $0-20 \mathrm{~cm}$ and $20-40 \mathrm{~cm}$.

Air-dried soil samples weighing $100 \mathrm{~g}$ were saturated with redistilled water to $150 \%$ of their full water capacity and then incubated at room temperature for $66 \mathrm{~h}$ to achieve ionic equilibrium between the solid and liquid phases. The solutions were filtered through blotting paper filters into polyethylene bottles and then frozen and stored for chemical analysis (Allen et al. 1974). Na determination was performed with a flame AAS (Perkin Elmer 1100 A). Cl was determined by potentiometric titration with an ion-selective electrode, and $\mathrm{pH}$ was determined by potentiometry using an Orion Star Plus apparatus (Thermo Scientific, USA) (LaCroix et al. 1970).

\section{Statistical analysis}

The results for all variables are presented as the means and standard deviations. Comparisons of means between groups (various $\mathrm{NaCl}$ levels or various damage indices) were based on one-way analysis of variance and Tukey's HSD test at the 0.05 significance level. Relationships between variables were evaluated using Pearson's correlation coefficient. For multivariate evaluation of the relationships between variables and multivariate characteristics of the groups, principal component analysis (PCA) was conducted. All analyses were performed using Statistica 13 software.

\section{Results and discussion}

In the field experiment, 134 street trees of T. $\times$ euchlora and 8 park trees (control) were examined to determine the damage index of leaves and their chemical composition. In mid-July, during leaf sample collection for chemical analysis, observations of leaf health status revealed only slight damage to a small number of trees. Therefore, this observation date was not included in further analyses. Observations from mid-September revealed a very large variation in leaf damage index values despite growing in practically the same soil. The following number of trees was detected in each category of leaf damage: "0"- $10.1 \%$ trees, " 1 " $-30.1 \%$, "2"-20.1\%, "3"-24.6\%, "4"-9.0\%, and "5"-6.0\%. In mid-September, $60 \%$ of street trees had damage to more than $25 \%$ of the leaf surfaces, which indicates the high sensitivity of this species to street conditions. The control (park) trees did not have any leaf damage on either observation date. In the pot experiment, in mid-July, only a few trees had slight leaf damage at the highest salt dose.

The publications describing T. $\times$ euchlora as sensitive were found (Roloff et al. 2009; Dmuchowski et al. 2020). In Warsaw, in 1973, T. $\times$ euchlora constituted $38 \%$ of street plantings in the city center; by $2007,62 \%$ had died and had been removed (Dmuchowski et al. 2011b). Our current research confirms the high sensitivity of $T . \times$ euchlora to street conditions in the urban environment.

Table 2 presents the results of soil analyses: the $\mathrm{pH}$ and $\mathrm{Cl}$ and $\mathrm{Na}$ contents of randomly selected trees from individual leaf damage categories with nine samples from each category and the contents of $\mathrm{Cl}^{-}$and $\mathrm{Na}^{+}$in the leaves of the trees in the field study. All other analyses included the results of leaf analyses from all 134 trees. The $\mathrm{pH}$ of street 
Table 2 The content of $\mathrm{Cl}$ and $\mathrm{Na}$ in the leaves of street trees Tilia $\times$ euchlora and control trees and in two layers of soil $(0-20 \mathrm{~cm}$ and $20-40 \mathrm{~cm}$ ) from under these trees with depending on the value of the leaf damage index

\begin{tabular}{|c|c|c|c|c|c|c|c|}
\hline \multirow{4}{*}{$\begin{array}{l}\text { Leaves- } \\
\text { dam- } \\
\text { ageindex }\end{array}$} & \multicolumn{2}{|l|}{ Leaves } & \multicolumn{5}{|l|}{ Soil } \\
\hline & \multirow{2}{*}{$\begin{array}{l}\mathrm{Cl} \\
(\%)\end{array}$} & \multirow{2}{*}{$\begin{array}{l}\mathrm{Na} \\
\mathrm{mg} \mathrm{kg}^{-1}\end{array}$} & \multirow[t]{2}{*}{$\mathrm{pH}$} & \multicolumn{2}{|l|}{$0-20 \mathrm{~cm}$} & \multicolumn{2}{|l|}{$20-40 \mathrm{~cm}$} \\
\hline & & & & $\mathrm{Cl}\left(\mathrm{mg} \mathrm{dm}^{-3}\right)$ & $\mathrm{Na}\left(\mathrm{mg} \mathrm{dm}^{-3}\right)$ & $\mathrm{Cl}\left(\mathrm{mg} \mathrm{dm}^{-3}\right)$ & $\mathrm{Na}\left(\mathrm{mg} \mathrm{dm}^{-3}\right)$ \\
\hline & Mean \pm SD & Mean \pm SD & Mean \pm SD & Mean \pm SD & Mean \pm SD & Mean \pm SD & Mean \pm SD \\
\hline 0 & $0.90 \pm 0.07 b$ & $179 \pm 50 \mathrm{a}$ & $7.45 \pm 0.28 b$ & $3073 \pm 801 b$ & $2101 \pm 301 b$ & $2673 \pm 1637 b$ & $1136 \pm 225 a b$ \\
\hline 1 & $1.15 \pm 0.16 \mathrm{c}$ & $222 \pm 25 a$ & $7.52 \pm 0.18 b$ & $3264 \pm 1135 b$ & $1899 \pm 620 \mathrm{ab}$ & $2252 \pm 464 a b$ & $1314 \pm 421 b$ \\
\hline 2 & $1.52 \pm 0.09 \mathrm{~d}$ & $250 \pm 42 a$ & $7.44 \pm 0.18 b$ & $3445 \pm 1135 b$ & $2133 \pm 676 b$ & $2703 \pm 858 b$ & $1410 \pm 447 b$ \\
\hline 3 & $1.54 \pm 0.08 \mathrm{~d}$ & $541 \pm 217 \mathrm{a}$ & $7.59 \pm 0.18 b$ & $3544 \pm 503 b$ & $2908 \pm 2061 b$ & $2741 \pm 1005 b$ & $1520 \pm 859 b$ \\
\hline 4 & $1.82 \pm 0.10 \mathrm{e}$ & $1217 \pm 317 b$ & $7.54 \pm 0.28 b$ & $3014 \pm 1014 b$ & $2238 \pm 965 b$ & $2636 \pm 359 b$ & $1326 \pm 301 b$ \\
\hline 5 & $1.95 \pm 0.21 \mathrm{e}$ & $3479 \pm 935 c$ & $7.61 \pm 0.27 b$ & $3385 \pm 1014 b$ & $2658 \pm 1099 b$ & $2696 \pm 359 b$ & $1458 \pm 301 b$ \\
\hline Contr. & $0.35 \pm 0.21 \mathrm{a}$ & $86 \pm 10 a$ & $6.35 \pm 0.72 \mathrm{a}$ & $1334 \pm 1014 a$ & $47 \pm 149 a b$ & $1333 \pm 359 a$ & $359 \pm 301 \mathrm{a}$ \\
\hline
\end{tabular}

Based on analysis of variance and Tukey's test different letters mean statistically significant differences between trees treated with different doses of $\mathrm{NaCl}$

soil ranged from 7.44 to 7.61 and was significantly higher than the park soil $\mathrm{pH}$ (6.35). Statistical analysis showed no significant differences in the soil $\mathrm{pH}$ of street soils in each variant (Table 2). The trends obtained are consistent with the literature data. Soil contamination with $\mathrm{NaCl}$ increases soil pH, which has adverse effects on trees (Park et al. 2010; Zhang et al. 2012). The contents of $\mathrm{Cl}^{-}$and $\mathrm{Na}^{+}$in street soil from the two depths were significantly higher than those in park soil. However, no significant differences were found among individual street soil variants. Moreover, no relationship was found between the content of $\mathrm{Cl}^{-}$and $\mathrm{Na}^{+}$in the leaves and their content in the soil collected from under the same trees. Moreover, the content of $\mathrm{Cl}^{-}$and $\mathrm{Na}^{+}$in the soil was accompanied by a very high standard deviation, which demonstrates large variability in the degree of soil salinity consistent with the literature data (Cekstere and Osvalde 2010). Determination of the content of elements in the leaves of trees provides important information, especially about the threat of pollution but also about their vitality, nutrition, growth conditions, and other threats, and this information may be more important than determining the chemical composition of the soil in urbanized areas (Cekstere et al. 2010; Mellert and Göttlein 2012; Dmuchowski et al. 2013). For these reasons, only the chemical composition of the leaves is discussed in the following sections.

Figure 1 presents the results of the leaf contents of $\mathrm{Cl}^{-}$and $\mathrm{Na}^{+}$, the ionic balance indicator and the sum of polyprenols based on the value of the leaf damage index. The content of $\mathrm{Cl}^{-}$increased with increasing degree of leaf damage from $0.98 \%$ at damage index " 0 " to $1.88 \%$ at damage index " 5 ", and the content was $0.35 \%$ in control trees. The corresponding contents of Na were $184 \mathrm{mg} \mathrm{kg}^{-1}$, $3479 \mathrm{mg} \mathrm{kg}^{-1}$, and $86 \mathrm{mg} \mathrm{kg}^{-1}$, respectively. Statistical analysis of the results showed that leaf damage index values was strongly positively correlated with the contents of $\mathrm{Cl}^{-}$and
$\mathrm{Na}^{+}$(Table 3). Many studies confirm our results (Goodrich and Jacobi 2012; Jimenez-Casas and Zwiazek 2014; CalvoPolanco et al. 2014; Helama et al. 2020).

The $\mathrm{Cl}$ content exceeded the level of $0.6 \%$ specified in the literature as being toxic to Tilia (Pauleit 1988; Chmielewski et al. 1996). For $\mathrm{Na}$, a similar toxicity level was not found in the literature. Significant soil contamination with $\mathrm{NaCl}$ affects practically all life processes of trees. The results include physiological drought, nutrient deficiencies and eventual tree death (Chen et al. 2010; Cekstere et al. 2020; Ordóñez-Barona et al. 2018). High $\mathrm{Na}^{+}$content in the leaves is not only toxic but can also limit the absorption of macroelements $(\mathrm{Ca}, \mathrm{K}$, and $\mathrm{Mg})$. Leaf damage is mainly caused by $\mathrm{Cl}^{-}$(Slabu et al. 2009; Genc et al. 2015). Salt stress can also increase the susceptibility of trees to pathogens (Munck et al. 2010; Snieškienè et al. 2016), but there have also been reports that salinity may reduce the number of aphids on linden leaves (Sienkiewicz-Paderewska et al. 2017; Bouraoui et al. 2019).

In the pot experiment, the contents of $\mathrm{Cl}^{-}$and $\mathrm{Na}^{+}$in the leaves increased significantly with increasing salt dose. $\mathrm{Cl}^{-}$increased from 0.33 to $2.08 \%$ in the control at $30 \mathrm{~g}$ per pot, and Na increased accordingly from 48 to $2865 \mathrm{mg} \mathrm{kg}^{-1}$.

Ion imbalance is considered the cause of the poor condition of street trees and their death, one of the causes of which is soil salinity (Mazher et al. 2007; Green et al. 2008). Figure 1 shows the relationship between the value of the ionic balance in the leaves and the street leaf damage index. The ionic balance indicator value decreased with the deterioration of leaf health from 2.56 at leaf damage index " 0 " to 0.56 at " 5 ", and the value in the control was 4.90 .

Differences between leaf damage index categories were significant, especially between trees with a higher leaf damage index. The chloride ion content, which strongly affected the value of the ionic balance, increased with the increase 

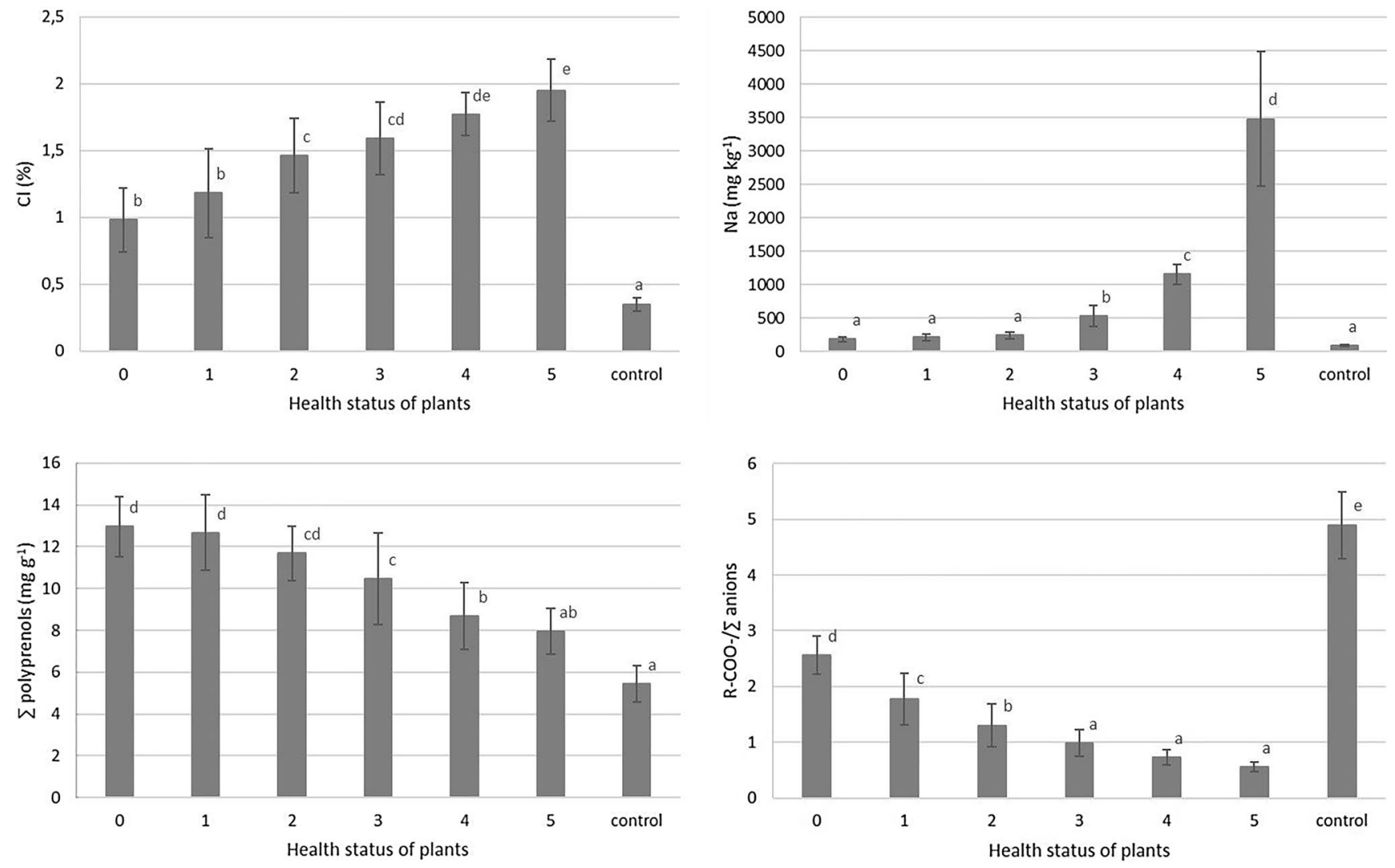

Fig. 1 The contents of $\mathrm{Cl}, \mathrm{Na}$, and polyprenols and the ionic balance index (means and SDs) in the leaves of street and control trees depending on the value of the leaf damage index. The results are

based on analysis of variance and Tukey's test (different letters indicate significant differences)
Table 3 Correlation coefficients and $P$ values between the $\mathrm{pH}$ and $\mathrm{Na}$ and $\mathrm{Cl}$ content in two layers of soil and leaves damage index and content of $\mathrm{Cl}$ and $\mathrm{Na}$ of the leaves of street Tilia $\times$ euchlora trees

\begin{tabular}{|c|c|c|c|c|c|c|}
\hline \multirow[t]{2}{*}{ Soil } & \multicolumn{2}{|c|}{ Leaves damage index } & \multicolumn{2}{|l|}{$\mathrm{Cl}$ leaves } & \multicolumn{2}{|l|}{$\mathrm{Na}$ leaves } \\
\hline & $\begin{array}{l}\text { Correlation } \\
\text { coefficient }\end{array}$ & $P$ value & $\begin{array}{l}\text { Correlation } \\
\text { coefficient }\end{array}$ & $P$ value & $\begin{array}{l}\text { Correlation } \\
\text { coefficient }\end{array}$ & $P$ value \\
\hline pH 0-20 & 0.216 & 0.116 & 0.161 & 0.246 & 0.222 & 0.139 \\
\hline $\mathrm{Cl} 0-20$ & 0.055 & 0.692 & 0.061 & 0.664 & 0.048 & 0.730 \\
\hline $\mathrm{Na} 0-20$ & 0.203 & 0.140 & 0.131 & 0.344 & 0.137 & 0.324 \\
\hline $\mathrm{Cl} 20-40$ & 0.069 & 0.620 & 0.018 & 0.900 & 0.026 & 0.853 \\
\hline $\mathrm{Na} 20-40$ & 0.162 & 0.241 & 0.103 & 0.457 & 0.032 & 0.819 \\
\hline
\end{tabular}

in the value of the leaf damage index. The pot experiment yielded the same trends as the field tests (Fig. 2). The differences between the experimental variants were significant, and the ionic balance indicator value decreased from 3.66. In the majority of studies, the content of elements in plants is given in units of weight (e.g., $\mathrm{mg} / \mathrm{kg}$ and \%), which is a gross simplification. Chemicals and ions react with each other not in equal weight proportions but in equivalent proportions depending on the atomic or ionic mass and valence. This fact significantly limits the possibility of comparing our own results with those of other studies. Brogowski et al. (2000) and Dmuchowski et al. (2011a) showed that an ionic balance indicator value less than one indicates poor conditions for street trees. In our research, trees with a damage index greater than "2" had an index of the ionic balance value less than one.

There are opinions about the role of polyprenols in mitigating biotic and abiotic stress, but the information remains very limited. The content of polyprenols in the leaves of street trees (Fig. 1) decreased from $13.0 \mathrm{mg} \mathrm{g}^{-1}$ in leaves without damages (index " 0 ") to $7.9 \mathrm{mg} \mathrm{g}^{-1}$ in those with the greatest damage (index " 5 "). Decreased content of polyprenols in the significantly damaged leaves comparing to that with slightly damaged most probably 

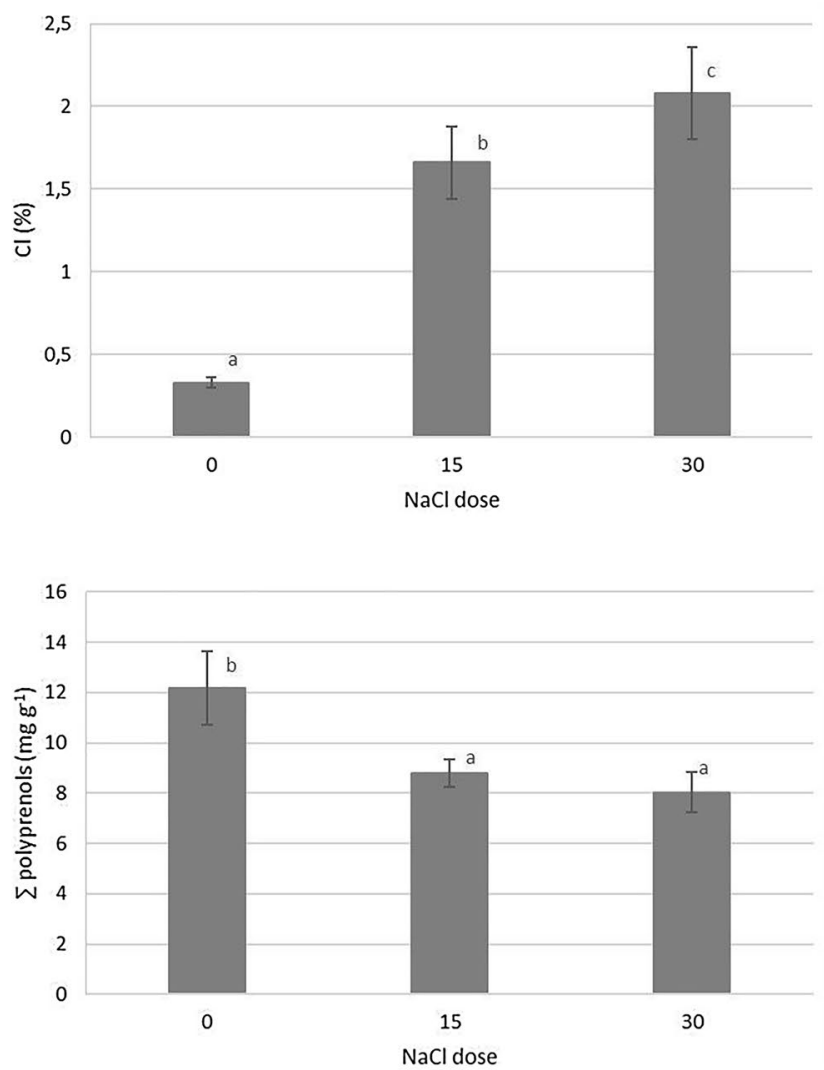

Fig. 2 The contents of $\mathrm{Cl}, \mathrm{Na}$, and polyprenols and the ionic balance index (means and SDs) in the leaves of the model pot trees depending on the dose of $\mathrm{NaCl}$ in the pot. The results are based on analysis of

result from the enhanced catabolic processes that occur in the former group of leaves which might lead to polyprenol decomposition. Importantly, control trees contained the lowest content of polyprenols at $5.4 \mathrm{mg} \mathrm{g}^{-1}$. Thus, on the one hand, exposition of the urban trees to salinity resulted in the increase of the content of polyprenols while on the other hand, the content of polyprenols decreased in the leaves of trees growing in saline soil as the content of $\mathrm{Cl}^{-}$and $\mathrm{Na}^{+}$increased. This latter observation might also be explained by the increased level of the reactive oxygen species (ROS) generated in the leaves of the significantly damaged (index "5") since ROS are able to break down polyprenols (Komaszylo née Siedlecka et al. 2916). In the pot experiment, the relationships were different. The leaves of control trees contained significantly more polyprenols $\left(12.3 \mathrm{mg} \mathrm{g}^{-1}\right)$ than did those of trees growing in saline soil. Between trees growing in both doses of soil salinity, the content of polyprenols in leaves did not differ significantly $\left(8.8 \mathrm{mg} \mathrm{g}^{-1}\right.$ and $\left.8.0 \mathrm{mg} \mathrm{g}^{-1}\right)$. Pot experiments do not provide an unequivocal answer as to whether increases in the $\mathrm{Cl}^{-}$and $\mathrm{Na}^{+}$contents in leaves increase the synthesis of polyprenols again indicating the importance of the urban model. Moreover, young plants used
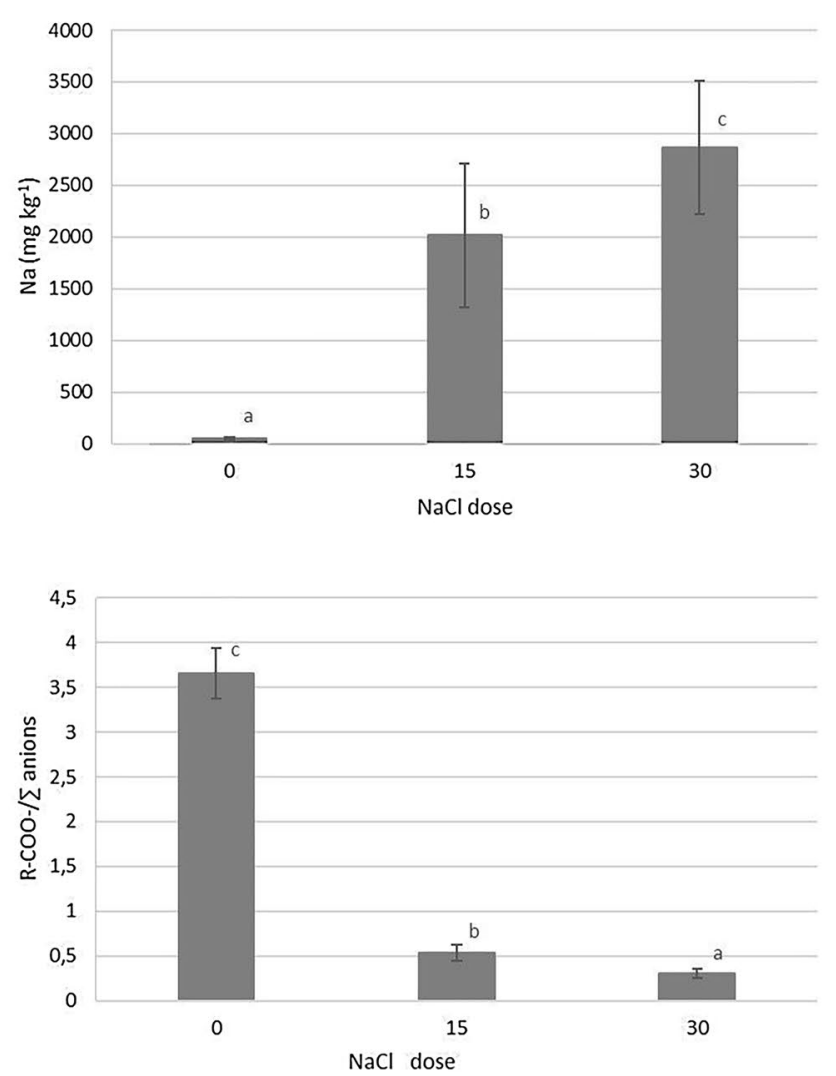

variance and Tukey's test (different letters indicate significant differences between trees treated with different doses of $\mathrm{NaCl}$ )

in the pot model might have possibly not developed the salinity-adaptive mechanisms observed for older plants.

Increasing of polyprenols in leaves of $T . \times$ euchlora as a reaction to salt stress has already been shown and has been interpreted as a method of adaptation to salinity, where the properties of polyprenols as free radical scavengers affect the transport of chloride and sodium to leaves (MilewskaHendel et al. 2017). Baczewska et al. 2014) suggested that polyprenols have an effect on reducing the acclimation of $\mathrm{Cl}$ in Tilia, and Dmuchowski et al. $(2019,2021)$ reported similar results for Gingko biloba and Acer. Polyprenols also reported protect mangroves from salty seawater (Basyuni et al. 2017). This protective function in leaves and roots can be realized in three ways: isolation, exclusion and management of salt accumulation (Basyuni et al. 2019).

The contents of macroelements in linden leaves from the field and pot experiments are presented in Table 4. In the leaves of street and control trees, the contents of $\mathrm{Ca}$ and $\mathrm{Mg}$ did not differ significantly regardless of the degree of damage to the leaves. Trees with greater leaf damage contained significantly less $\mathrm{N}$ and $\mathrm{K}$ than healthier and control trees. In the case of $\mathrm{P}$, control trees contained more $\mathrm{P}$ compared 
Table 4 Means and SDs for the content of macronutrients in street trees depending on the value of the leaf damage index and in the leaves from the pot experiment treated with different doses of $\mathrm{NaCl}$

\begin{tabular}{|c|c|c|c|c|c|}
\hline \multirow[t]{2}{*}{ Leaf damage index } & $\mathrm{N}(\%)$ & $\mathrm{P}(\%)$ & $\mathrm{K}(\%)$ & $\mathrm{Ca}(\%)$ & $\operatorname{Mg}(\%)$ \\
\hline & Mean \pm SD & Mean \pm SD & Mean \pm SD & Mean \pm SD & Mean \pm SD \\
\hline \multicolumn{6}{|l|}{ Field experiment } \\
\hline 0 & $3.01 \pm 0.13 \mathrm{c}$ & $0.43 \pm 0.10 \mathrm{a}$ & $1.78 \pm 0.24 \mathrm{c}$ & $2.27 \pm 0.26 \mathrm{a}$ & $0.36 \pm 0.09 a$ \\
\hline 1 & $3.02 \pm 0.24 \mathrm{c}$ & $0.44 \pm 0.06 \mathrm{a}$ & $1.75 \pm 0.30 \mathrm{c}$ & $2.26 \pm 0.41 \mathrm{a}$ & $0.37 \pm 0.09 a$ \\
\hline 2 & $3.01 \pm 0.22 \mathrm{c}$ & $0.39 \pm 0.14 a$ & $1.77 \pm 0.19 \mathrm{c}$ & $2.19 \pm 0.29 a$ & $0.38 \pm 0.10 \mathrm{a}$ \\
\hline 3 & $2.63 \pm 0.24 b$ & $0.41 \pm 0.06 \mathrm{a}$ & $1.61 \pm 0.19 b c$ & $2.16 \pm 0.58 \mathrm{a}$ & $0.36 \pm 0.12 \mathrm{a}$ \\
\hline 4 & $2.49 \pm 0.24 \mathrm{ab}$ & $0.42 \pm 0.12 \mathrm{a}$ & $1.39 \pm 0.19 \mathrm{ab}$ & $1.99 \pm 0.41 \mathrm{a}$ & $0.34 \pm 0.15 a$ \\
\hline 5 & $2.31 \pm 0.24 \mathrm{a}$ & $0.40 \pm 0.07 \mathrm{a}$ & $1.05 \pm 0.20 \mathrm{a}$ & $1.87 \pm 0.20 \mathrm{a}$ & $0.33 \pm 0.07 a$ \\
\hline Control & $3.14 \pm 0.21 \mathrm{c}$ & $0.59 \pm 0.10 \mathrm{~b}$ & $1.52 \pm 0.20 \mathrm{bc}$ & $2.24 \pm 0.20 \mathrm{a}$ & $0.38 \pm 0.07 \mathrm{a}$ \\
\hline Dose & $\mathrm{N}(\%)$ & $\mathrm{P}(\%)$ & $\mathrm{K}(\%)$ & $\mathrm{Ca}(\%)$ & $\operatorname{Mg}(\%)$ \\
\hline $\mathrm{g} \mathrm{NaCl} /$ pot & Mean \pm SD & Mean \pm SD & Mean \pm SD & Mean \pm SD & Mean \pm SD \\
\hline \multicolumn{6}{|l|}{ Pot experiment } \\
\hline 0 & $2.43 \pm 0.17 \mathrm{a}$ & $0.42 \pm 0.06 \mathrm{a}$ & $1.23 \pm 0.10 \mathrm{a}$ & $1.10 \pm 0.13 b$ & $0.25 \pm 0.10 \mathrm{a}$ \\
\hline 15 & $2.37 \pm 0.23 \mathrm{a}$ & $0.38 \pm 0.05 a$ & $1.48 \pm 0.23 \mathrm{ab}$ & $1.09 \pm 0.08 b$ & $0.27 \pm 0.04 \mathrm{a}$ \\
\hline 30 & $2.23 \pm 0.16 \mathrm{a}$ & $0.36 \pm 0.05 \mathrm{a}$ & $1.65 \pm 0.25 b$ & $0.88 \pm 0.09 a$ & $0.28 \pm 0.03 a$ \\
\hline
\end{tabular}

Based on analysis of variance and Tukey's test different letters mean statistically significant differences between trees treated with different doses of $\mathrm{NaCl}$

with all categories of street trees. In the pot experiment, soil salinity did not affect the contents of $\mathrm{N}, \mathrm{P}$ or $\mathrm{Mg}$ in leaves.

Analysis of the contents of macronutrients in the leaves did not provide a clear answer. Previously published data indicate that the content of macroelements $(\mathrm{N}, \mathrm{P}, \mathrm{K}, \mathrm{Ca}$ and $\mathrm{Mg}$ ) in the leaves was at the level considered "normal" and often optimal. Deficient levels were not found in any experimental variant (Dirr 1976; Mellert et al. 2012; Kopinga and Van den Burg 1995; De Vries et al. 2000). The same tendencies were observed by Cekserte et al. (2020) in studies on street $T . \times$ vulgaris in Riga (Latvia). The relationship between soil salinity and mineral uptake is not simple. Salinity may increase, decrease or have no effect on
Fig. 3 Results of PCA based on the first and second principal components (PC1 and PC2) presenting multivariate relationships between variables and multivariate differences between groups with various levels of the leaf damage index

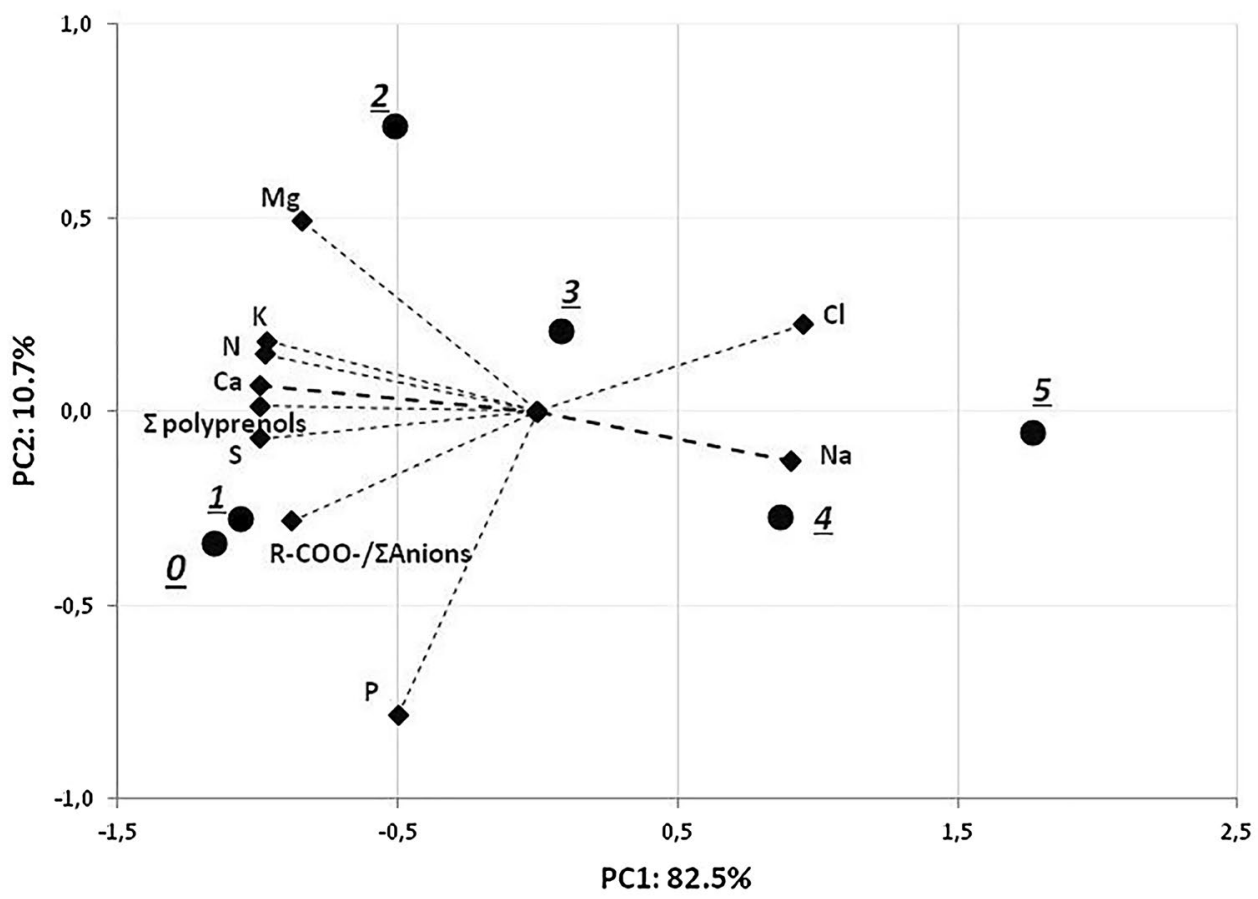


the content of macronutrients in plants (Green et al. 2008; Dmuchowski et al. 2914).

In the field experiment (Fig. 3), PCA results showed a strong positive correlation between the contents of $\mathrm{Na}$ and $\mathrm{Cl}$ in leaves, which were negatively correlated with other elements, with the exception of P. High contents of most elements, polyprenols and indicators of ionic balance in plants were observed for low leaf damage rates ("0" and " 1 "). An increase in the leaf damage index was positively correlated with the contents of $\mathrm{Na}^{+}$and $\mathrm{Cl}^{-}$and negatively correlated with the contents of other elements and polyprenols and the indicator of ionic balance.

The results of PCA for the pot experiment demonstrate a strong positive correlation between $\mathrm{Na}, \mathrm{Cl}, \mathrm{Mg}$ and $\mathrm{K}$, which were negatively correlated with $\mathrm{Ca}, \mathrm{N}, \mathrm{P}$, polyprenols and ionic balance (Fig. 4). For the group without $\mathrm{NaCl}(0 \mathrm{~g}$ $\mathrm{NaCl}$ ), high contents of $\mathrm{P}, \mathrm{N}, \mathrm{Ca}$, and polyprenols and high values of ionic balance were observed. For the group with the highest $\mathrm{NaCl}$ dose $(30 \mathrm{~g} \mathrm{NaCl})$, high contents of $\mathrm{Na}, \mathrm{Cl}$, $\mathrm{K}$ and $\mathrm{Mg}$ were observed.

\section{Conclusions}

In accordance with previous publications, T. $\times$ euchlora exhibited a lack of resistance to urban street conditions. Although they grew in the same soil conditions, the health of trees was very diverse. This diversity was expressed as a strongly significant positive correlation between the contents of $\mathrm{Cl}^{-}$and $\mathrm{Na}^{+}$and the value of the leaf damage index, value of ionic balance and content of polyprenols. The trees with the most damaged leaves had an ionic balance that was 4.5-fold less compared with trees with the least damage and 8.7-fold less compared with control trees. The contents of $\mathrm{Na}^{+}$and $\mathrm{Cl}^{-}$in the leaves were negatively correlated with $\mathrm{N}, \mathrm{K}, \mathrm{Ca}$ and $\mathrm{Mg}$, indicating a disturbed ionic balance, but no deficiencies in any bioelements were found. In the pot experiment, similar relationships were found with the only difference being that negative correlations were found for $\mathrm{P}$ instead of $\mathrm{K}$ and $\mathrm{Mg}$. The differences between young trees from the pot experiment and older trees from the field were expressed in their ability to synthesize polyprenols. Under street conditions, the leaves of trees with with slight damage contained more polyprenols than heavily damaged leaves. The leaves of control (nonsaline) trees contained significantly fewer polyprenols. The ability to synthesize polyprenols acquired in the process of acclimation by mature trees may be a method of mitigating salt stress. In the pot experiment, the reactions of the trees were completely different. The pot experiment method allows all other factors besides salt stress that may affect the health of plants to be eliminated. Control trees contained more polyprenols compared with those treated with $\mathrm{NaCl}$. The dose of salt had no significant effect on polyprenol levels. Young trees may not have had time for acclimation to develop the ability to synthesize more polyprenols. Plants have developed many methods of protection against salt stress. Our results suggest that one of these methods for the mitigation of salt stress by trees may be the ability to synthesize more polyprenols. It seems likely
Fig. 4 Results of PCA based on the first and second principal components (PC1 and PC2) presenting multivariate relationships between variables and multivariate differences between the experimental groups $(0,15$, and $30 \mathrm{~g}$ of $\mathrm{NaCl}$ per pot)

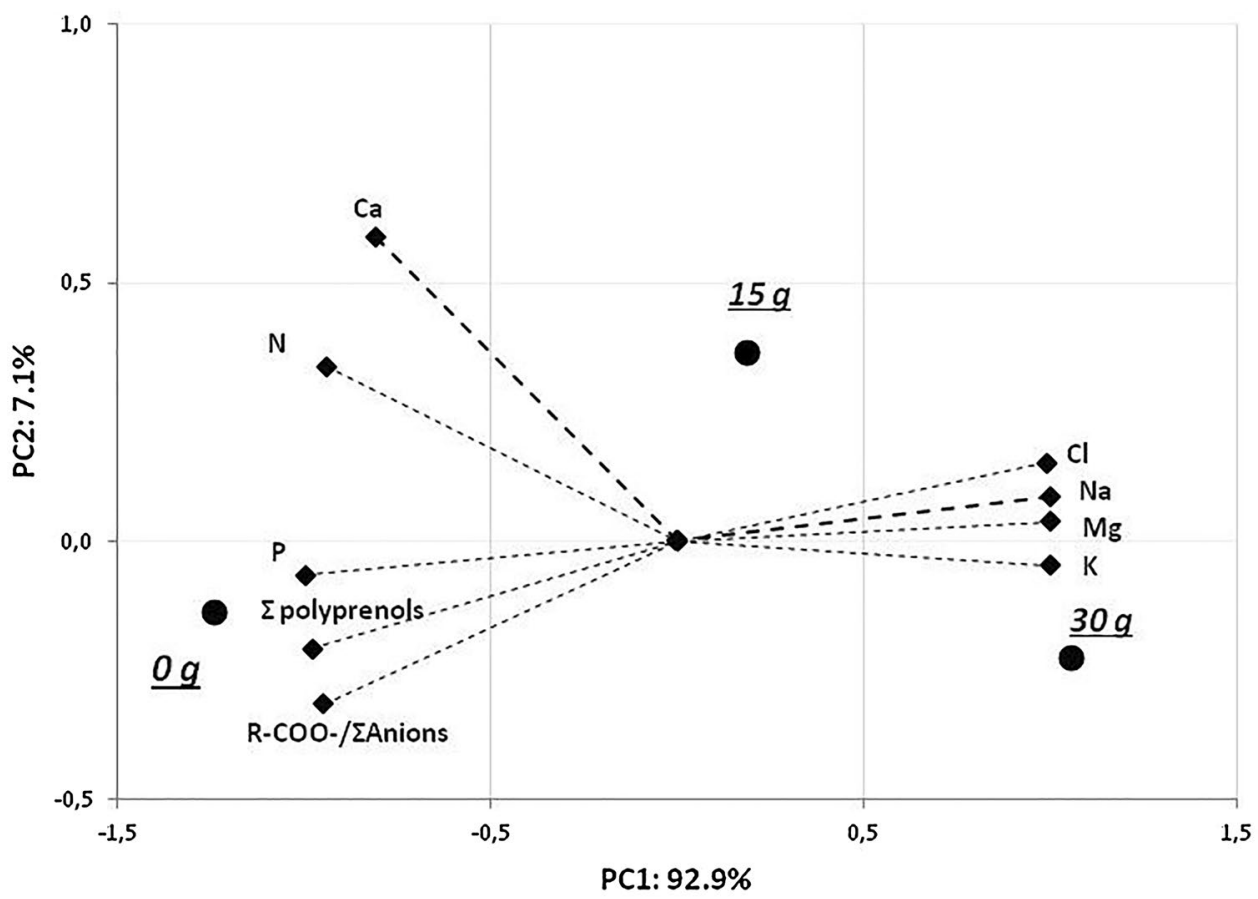


that this mitigation could be by blocking $\mathrm{Cl}^{-}$and $\mathrm{Na}^{+}$from entering the leaves.

Author contribution statement AH B-D and WD led the writing of the manuscript. AH B-D, WD, AJ, and ES conceived the hypothesis, AJ, AH B-D, and DG designed the methodology, and analyzed the data. All the authors (AH $\mathrm{B}-\mathrm{D}, \mathrm{WD}$, IS, ES, AJ, DG, PD, and BG) contributed to data interpretation and discussion and substantially improved the final draft of the manuscript.

Acknowledgements This investigation was partially supported by a grant from the National Science Centre of Poland (UMO-2018/29/B/ NZ3/01033).

\section{Declarations}

Conflict of interest The authors declare no conflict of interest.

Open Access This article is licensed under a Creative Commons Attribution 4.0 International License, which permits use, sharing, adaptation, distribution and reproduction in any medium or format, as long as you give appropriate credit to the original author(s) and the source, provide a link to the Creative Commons licence, and indicate if changes were made. The images or other third party material in this article are included in the article's Creative Commons licence, unless indicated otherwise in a credit line to the material. If material is not included in the article's Creative Commons licence and your intended use is not permitted by statutory regulation or exceeds the permitted use, you will need to obtain permission directly from the copyright holder. To view a copy of this licence, visit http://creativecommons.org/licenses/by/4.0/.

\section{References}

Akhtar TA, Surowiecki P, Siekierska H, Kania M, Van Gelder et al (2017) Polyprenols are synthesized by a plastidial cis-prenyltransferase and influence photosynthetic performance. Plant Cell 29:1709-1725. https://doi.org/10.1105/tpc.16.00796

Allen SE, Grimshaw HN, Parkinson JA, Quarmby C (1974) Chemical analysis of ecological materials. Blackwell, Oxford

Baczewska AH, Dmuchowski W, Jóźwiak A, Gazdowski D, Bragoszewska P et al (2014) Effect of salt stress on prenol lipids in the leaves of Crimean linden (Tilia 'Euchlora'). Dendrobiology 72:177-186. https://doi.org/10.12857/denbio.-72.015

Baetz U, Eisenach C, Tohge T, Martinoia E, De Angeli A (2016) Vacuolar chloride fluxes impact ion content and distribution during early salinity stress. Plant Physiol 172:1167-1181. https://doi.org/ $10.1104 / p p .16 .00183$

Bajda A, Chojnicki T, Hertel J, Swiezewska E, Wójcik J et al (2005) Light conditions alter accumulation of long chain polyprenols in leaves of trees and shrubs throughout the vegetation season. Acta Biochim Pol 52:233-241. https://doi.org/10.18388/abp.2005 3514

Bajda A, Konopna-Postupolska D, Krzymowska M, Hennig J, Skorupinska-Tudek K et al (2009) Role of polyisoprenoids in tobacco resistance against biotic stresses. Physiol Plant 135:351364. https://doi.org/10.1111/j.1399-3054.2009.01204.x
Baraldi R, Przybysz A, Facini O, Pierdonà L, Carriero G et al (2019) Impact of drought and salinity on Sweetgum Tree (Liquidambar styraciflua L.): understanding tree ecophysiological responses in the urban context. Forests 10:1032. https://doi.org/10.3390/f1011 1032

Basyuni M, Sagami H, Baba S, Putri LA, Wati R et al (2017) Salinity alters the polyisoprenoid alcohol content and composition of both salt-secreting and non-salt-secreting Mangrove seedlings. HAYATI J Biosci 24:206-214. https://doi.org/10.1016/j.hjb. 2017.11.006

Basyuni M, Wasilah M, Hasibuan PAZ, Sulistiyono N, Sumardi S et al (2019) Salinity and subsequent freshwater influences on the growth, biomass, and polyisoprenoids distribution of Rhizophora apiculata seedlings. Biodiversitas 20:388-395. https://doi.org/10. 13057/biodiv/d200146

Bergamini E (2003) Dolichol: an essential part in the antioxidant machinery of cell membranes. Biogerontology 4:337-339. https:// doi.org/10.1023/B:BGEN.0000006637.48753.07

Blomqvist G (1998) Impact of de-icing salt on roadside vegetation: a literature review. Swedish National Road and Transport Research Institute, VTI rapport 427A

Bouraoui D, Cekstere G, Osvalde A, Vollenweider P, Rasmann S (2019) Deicing salt pollution affects the foliar traits and arthropods' biodiversity of lime trees in Riga's street greeneries. Front Ecol Evol 7:282

Brogowski Z, Zagórski Z, Czarnowska K, Chojnicki J, Pracz J (2000) Influence of salt stress on the chemical composition of tree leaves from the Łodź city area. Soil Sci Ann 51:17-28

Calvo-Polanco M, Equiza MA, Señorans J, Zwiazek JJ (2014) Responses of rat root (Acorus americanus Raf.) plants to salinity and $\mathrm{pH}$ conditions. J Environ Qual 43:578-586. https://doi.org/ 10.2134/jeq2013.07.0266

Cekstere G, Osvalde A (2010) Macronutrient status in the differentaged lime trees (Tilia $\times$ vulgaris $\mathrm{H}$.) in Riga Streets. Balt For $16: 16-22$

Cekstere G, Osvalde A, Nikodemus O (2010) Nutrient accumulation in street greenery of Riga (Lativa) in increased salinity conditions, 2005 and 2007. Anadolu J Agric Sci 25:192-198

Cekstere G, Osvalde A, Elferts D, Rose C, Lucas F et al (2020) Salt accumulation and effects within foliage of emopenTiliaemclose $\times$ emopenvulgarisemclose trees from the street greenery of Riga. Sci Total Environ, Latvia. https://doi.org/10.1016/j.scitotenv.2020. 140921

Chen L, Zhang S, Zhao H, Korpelainen H, Li C (2010) Sex-related adaptive responses to interaction of drought and salinity in Populus yunnanensis. Plant Cell Environ 33:1767-1778. https://doi. org/10.1111/j.1365-3040.2010.02182.x

Chmielewski W, Dmuchowski W, Supłat S (1999) Impact of urban environmental pollution on growth, leaf damage and chemical constituents of Warsaw Urban Trees. In: Proceedings of the international symposium on air pollution and climate change affects on forest ecosystems, Riverside, USA, February 5-9, 1996, USDA Forest Service, General Technical Report, PSW-GTR-166, pp\&nbsp;215-220

Dadvand P, Bartoll X, Basagaña X, Dalmau-Bueno D, Martinez A et al (2016) Green spaces and general health: roles of mental health status, social support, and physical activity. Environ Int 91:161-167. https://doi.org/10.1016/j.envint.2016.02.029

De Vries W, Reinds GJ, van Kerkvoorde MS, Hendriks CMA, Leeters EEJM et al (2000) Intensive monitoring of forest ecosystems in Europe. In: Technical report, EC, UN/ECE, Brussels, Geneva

De Wit CT, Dijkshoorn W, Noggle JG (1963) Ionic balance and growth of plants. Verslagen van Landbouwkunde Onderzoeken 69:1-68

Dirr MA (1976) Selection of trees for tolerance to salt injury. J Arboric 2:209-216 
Dmuchowski W, Brogowski Z, Baczewska AH (2011a) Evaluation of vigour and health of street trees using the foliar ionic status. Pol J Environ Stud 20:489-496

Dmuchowski W, Baczewska AH, Brągoszewska P (2011b) Reaction of street trees to adverse environmental conditions in the centre of Warsaw. Ecol Quest 15:97-105. https://doi.org/10.12775/ v10090-011-0041-4

Dmuchowski W, Baczewska AH, Gozdowski D, Brągoszewska P (2013) Effect of salt stress on the chemical composition of leaves of different trees species in urban environment. Fresenius Environ Bull 22:987-994

Dmuchowski W, Brągoszewska P, Gozdowski D, BaczewskaDabrowska AH, Chojnacki T et al (2019) Strategy of Ginkgo biloba\&nbsp;L. in the mitigation of salt stress in the urban environment. Urban For Urban Green 38:223-23. https://doi.org/10. 1016/j.ufug.2019.01.003

Dmuchowski W, Brągoszewska P, Gozdowski D, BaczewskaDąbrowska AH, Chojnacki T et al (2020) Strategies of urban trees for mitigating salt stress: a case study of eight plant species. Teres. https://doi.org/10.1007/s00468-020-02044-0

Dmuchowski W, Baczewska-Dąbrowska A, Gozdowski D, Brągoszewska P et al (2021) Effect of salt stress in urban conditions on two Acer species with different sensitivity. PeerJ 9:e10577. https://doi.org/10.7717/peerj.10577

Equiza MA, Calvo-Polanco M, Cirelli D, Señorans J, Wartenbe M et al (2017) Long-term impact of road salt $(\mathrm{NaCl})$ on soil and urban trees in Edmonton, Canada. Urban For Urban Green 2:16-28. https://doi.org/10.1016/j.ufug.2016.11.003

Genc Y, Oldach K, Taylor J, Lyons GH (2015) Uncoupling of sodium and chloride to assist breeding for salinity tolerance in crops. New Phytol 210:145-156. https://doi.org/10.1111/nph.13757

Goodrich BA, Jacobi WR (2012) Foliar damage, ion content, and mortality rate of five common roadside tree species treated with soil applications of magnesium chloride. Water Air Soil Pollut 223:847-862. doi https://doi.org/10.1007/s11270-011-0907-5

Green SM, Machin R, Cresser MS (2008) Effect of long-term changes in soil chemistry induced by road salt applications on $\mathrm{N}$ transformations in roadside soils. Environ Pollut 152:20-31. https://doi. org/10.1016/j.envpol.2007.06.005

Gutkowska M, Bienkowski T, Hung VS, Wanke M, Hertel J (2004) Proteins are polyisoprenylated in Arabidopsis thaliana. Biochem Biophys Res Comun 322:998-1004. https://doi.org/10.1016/j. bbrc.2004.08.025

Hallett R, Johnson ML, Sonti NF (2018) Assessing the tree health impacts of salt water flooding in coastal cities: a case study in New York City. Landsc Urban Plan 177:171-177. https://doi.org/ 10.1016/j.landurbplan.2018.05.004

Helama S, Läänelaid A, Raisio J, Sohar K, Mäkelä A (2020) Growth patterns of roadside Tilia spp. affected by climate and street maintenance in Helsinki. Urban For Urban Green 53:126707. https:// doi.org/10.1016/j.ufug.2020.126707

Jimenez-Casas M, Związek JJ (2014) Adventitious sprouting of Pinus leiophylla in response to salt stress. Ann For Sci 71:811-819. https://doi.org/10.1007/s13595-014-0379-Z

Jozwiak A, Brzozowski R, Bujnowski Z, Chojnicki T, Swiezewska E (2013) Application of supercritical $\mathrm{CO}_{2}$ for extraction of polyisoprenoid alcohols and their esters from plant tissues. J Lipid Res 54:2023-2028. https://doi.org/10.1194/jlr.D038794

Kopinga J, Van den Burg J (1995) Using soil and foliar analysis to diagnose the nutritional status of urban trees. J Arboric 21:17-24

LaCroix RL, Keeney DR, Walsh LM (1970) Potentiometric titration of chloride in plant tissue extracts using the chloride ion electrode. Soil Sci Plant Anal 1(1):1-6

Livesley SJ, McPherson EG, Calfapietra C (2016) The urban forest and ecosystem services: impacts on urban water, heat, and pollution cycles at the tree, street, and city scale. J Environ Qual 45:119124. https://doi.org/10.2134/jeq2015.11.0567

Łuczak K, Czerniawska-Kusza I, Rosik-Dulewska C, Kusza G (2021) Effect of $\mathrm{NaCl}$ road salt on the ionic composition of soils and Aesculus hippocastanum L. foliage and leaf damage intensity. Sci Rep 11:1-10. https://doi.org/10.1038/s41598-021-84541-x

Martin MP, Simmons C, Ashton MS (2016) Survival is not enough: the effects of microclimate on the growth and health of three common urban tree species in San Francisco, California. Urban For Urban Green 19:1-6. https://doi.org/10.1016/j.ufug.2016.06.004

Mazher AAM, Yassen AA, Zaghloul SM (2007) Influence of foliar application of potassium on growth and chemical composition of Bauhia variegate seedlings under different irrigation intervals. World J Agric Sci 3:23-31

McPherson EG (2004) Benefits of trees. Watershed, energy and air. Arborist News 13:29-35

Mellert KH, Göttlein A (2012) Comparison of new foliar nutrient thresholds derived from van den Burg's literature compilation with established central European references. Eur J Forest Res 131:1461-1472. https://doi.org/10.1007/s10342-012-0615-8

Milewska-Hendel A, Baczewska AH, Sala K, Dmuchowski W, Bragoszewska P (2017) Quantitative and qualitative characteristics of cell wall components and prenyl lipids in the leaves of Tilia $\times \& n b s p$; euchlora trees growing under salt stress. PLoS One 12:e172682. https://doi.org/10.1371/journal.pone.0172682

Munck IA, Bennet CM, Camilli KS, Nowak RS (2010) Long-term impact of de-icing salts on tree health in the Lake Tahoe Basin: environmental influences and interactions with insects and diseases. Forest Ecol Manag 260:1218-1229. https://doi.org/10. 1016/j.foreco.2010.07.015

Nikolaeva O, Tikhonov V, Vecherskii M, Kostina N, Fedoseeva E et al (2019) Ecotoxicological effects of traffic-related pollutants in roadside soils of Moscow. Ecotoxicol Environ Saf 172:538-546. doi:https://doi.org/10.1016/j.ecoenv.2019.01.068

Olchowik J, Suchocka M, Jankowski P, Malewski T, Hilszczańska D (2021) The ectomycorrhizal community of urban linden trees in Gdańsk, Poland. PLoS One 16:e0237551. https://doi.org/10.1371/ journal.pone. 0237551

Ordóñez-Barona C, Sabetski V, Millward AA, Steenberg J (2018) De-icing salt contamination reduces urban tree performance in structural soil cells. Environ Pollut 234:562-571. https://doi.org/ 10.1016/j.envpol.2017.11.101

Parihar P, Singh S, Singh R, Singh VP, Prasad SM (2015) Effect of salinity stress on plants and its tolerance strategies: a review. Environ Sci Pollut Res 2:4056-4075. https://doi.org/10.1007/ s11356-014-3739-1

Park SJ, Cheng Z, Yang H, Morris EE, Sutherland M (2010) Differences in soil chemical properties with distance to roads and age of development in urban areas. Urban Ecosyst 13:483-497. https:// doi.org/10.1007/s11252-010-0130-y

Pauleit S (1988) Vitalitätskartierung von Stadtbäume in Mŭnchen. Garten + Landschraft 7:38-40

Pauleit S, Jones N, Garcia-Martin G, Garcia-Valdecantos JL, Rivière LM (2002) Tree establishment practice in towns and citiesresults from a European survey. Urban For Urban Green 1:83-96. https://doi.org/10.1078/1618-8667-00009

Roloff A, Korn S, Gillner S (2009) The climate-species-matrix to select tree species for urban habitats considering climate change. Urban For Urban Green 8:295-308. https://doi.org/10.1016/j.ufug.2009. 08.002

Sarker U, Oba S (2018) Response of nutrients, minerals, antioxidant leaf pigments, vitamins, polyphenol, flavonoid and antioxidant activity in selected vegetable amaranth under four soil water content. Food Chem 252:72-83. https://doi.org/10.1016/j.foodchem. 2018.01.097 
Sarker U, Oba S (2020) The response of salinity stress-induced A. tricolor to growth, anatomy, physiology, non-enzymatic and enzymatic antioxidants. Front Plant Sci 11:559876. https://doi.org/10. 3389/fpls.2020.559876

Satish L, Shamili S, Yolcu S, Lavanya G, Alavilli H, Swamy MK (2020) Biosynthesis of secondary metabolites in plants as influenced by different factors. In Plant-derived Bioactives. Springer, Singapore, pp 61-100

Shelke DB, Nikalje GC, Nikam T, Maheshwari P, Punita DL (2019) Chloride $\left(\mathrm{Cl}^{-}\right)$uptake, transport, and regulation in plant salt tolerance. In: Roychoudhury A, Tripathi D (eds) Molecular plant abiotic stress: biology and biotechnology. Wiley, Chichester, pp 241-268. https://doi.org/10.1002/9781119463665.ch13

Sienkiewicz-Paderewska D, Dmuchowski W, Baczewska AH, Brągoszewska P, Gozdowski D (2017) The effect of salt stress on lime aphid abundance on Crimean linden (Tilia 'Euchlora') leaves. Urban For Urban Green 21:74-79. https://doi.org/10. 1016/j.ufug.2016.11.010

Skorupińska-Tudek K, Wojcik J, Swiezewska E (2008) Polyisoprenoid alcohols-recent results of structural studies. Chem Rec 8:33-45. https://doi.org/10.1002/tcr.20137

Slabu C, Zörb C, Steffens D, Schubert S (2009) Is salt stress of faba bean (Vicia faba) caused by $\mathrm{Na}^{+}$or $\mathrm{Cl}^{-}$toxicity? J Plant Nutr Soil Sci 172:644-651. https://doi.org/10.1002/jpln.200900052

Snieškienė V, Baležentienė L, Stankevičienè A (2016) Urban salt contamination impact on tree health and the prevalence of fungi agent in cities of the central Lithuania. Urban For Urban Green 19:13-19. https://doi.org/10.1016/j.ufug.2016.05.015

Swiezewska E, Sasak W, Mankowski T, Jankowski W, Vogtman T, Krajewska I, Hertel J, Skoczylas E, Chojnacki T (1994) The search for plant polyprenols. Acta Biochimica Polonae 41:221-260

Swiezewska E, Danikiewicz W (2005) Polyisoprenoids: structure, biosynthesis and function. Prog Lipid Res 44:235-258. https://doi. org/10.1016/j.plipres.2005.05.002
Van Tuil HD, Lampe JEM, Dijkshoorn W (1964) The possibility of relating the ash alkalinity to the organic-salt content. Jaarbook Instituut voor Biologisch Sheikundig Onderzoek van Landbougewassen, pp 157-160

Weryszko-Chmielewska E, Piotrowska-Weryszko K, Dąbrowska A (2019) Response of Tilia sp. L. to climate warming in urban conditions - phenological and aerobiological studies. Urban For Urban Green 43:126369. https://doi.org/10.1016/j.ufug.2019. 126369

Zhang H, Ohyama K, Boudet J, Chen Z, Yang J (2008) Dolichol biosynthesis and its effects on the unfolded protein response and abiotic stress resistance in Arabidopsis. Plant Cell 20:1879-1898. https://doi.org/10.1105/tpc.108.061150

Zhang Y, Li FY, Sun TT, Wang JL (2012) Effect of deicing salts on urban soils and the health of roadside pines (Pinus tabulaeformis) in Northeast China. Appl Mech Mater 178:353-356. https://doi. org/10.4028/www.scientific.net/AMM.178-181.353

Zhao H, Liang H, Chu Y, Sun C, Wei N et al (2019) Effects of salt stress on chlorophyll fluorescence and the antioxidant system in Ginkgo biloba L. seedlings. HortScience 54:2125-2133. https:// doi.org/10.21273/HORTSCI14432-19

Zhou Q, Shi M, Zhu Z, Cheng L (2019) Ecophysiological responses of Carpinus turczaninowii\&nbsp; L. to various salinity treatments. Forests 10:96. https://doi.org/10.3390/f10020096

Zwiazek JJ, Equiza MA, Karst J, Senorans J, Wartenbe M (2019) Role of urban ectomycorrhizal fungi in improving the tolerance of lodgepole pine (Pinus contorta) seedlings to salt stress. Mycorrhiza 29:303-312. https://doi.org/10.1007/s00572-019-00893-3

Publisher's Note Springer Nature remains neutral with regard to jurisdictional claims in published maps and institutional affiliations. 